\title{
Tindak Pidana Mengiklankan Hasil Usaha Perkebunan Yang Menyesatkan Konsumen
}

\section{Criminal Acts Advertise the Results of Plantation Businesses That Mislead Consumers}

\author{
Winda*, Kelvin Tedja \& Kartina Pakpahan**
}

Program Studi Ilmu Hukum, Fakultas Hukum, Universitas Prima Indonesia, Indonesia Diterima: 30 Mei 2020; Disetujui: 01 Agustus 2020; Dipublish: 08 Agustus 2020

${ }^{*}$ Coresponding Email: $\underline{\text { meimei280298@gmail.com; }}{ }^{* *}$ email: kartinapakpahan@unprimdn.ac.id \begin{abstract}
Abstrak
Tujuan penelitian ini adalah untuk menganalisis pengaturan tindak pidana pelaku usaha mengiklankan hasil usaha perkebunan menyesatkan konsumen dan upaya penanggulangan kejahatan tersebut serta bagaimana hukuman bagi pelaku tindak pidana mengiklankan hasil usaha perkebunan yang menyesatkan konsumen. Jenis Penelitian yuridis normatif. Sifat penelitian deskriptif, Analisis data kualitatif. Iklan menyesatkan hasil usaha perkebunan diatur Pasal 378 KUHP secara umum, dan secara khusus dalam Pasal 10 UUPK, Pasal 79 UU No.39 Tahun 2014 Tentang Perkebunan, Pasal 45 ayat (2) PP Nomor 69 Tahun 1999, Pasal 48 PP Nomor 71 Tahun 2019 dan Pasal 5 PEMKES Nomor 1787/MENKES/ PER/XII/2010. Upaya penanggulangan dilakukan preventif dan represif. Hukuman dikenakan Pasal 378 KUHP, Pasal 63 UUPK dan Pasal 112 UU Perkebunan.
\end{abstract}

Kata Kunci: Pelaku Usaha, Mengiklankan, Hasil Usaha Perkebunan, Menyesatkan Konsumen

\begin{abstract}
The purpose of this study is to analyze the regulation of criminal acts of businesses that advertise the results of plantation businesses misleading consumers and efforts to tackle these crimes and how the penalties for perpetrators of criminal acts advertise the results of plantation businesses that mislead consumers. Type of normative juridical research. The nature of descriptive research, analysis of qualitative data. Misleading advertisements of plantation business results are regulated in Article 378 of the Criminal Code in general, and specifically in Article 10 of the UUPK, Article 79 of Law No.39 of 2014 concerning Plantations, Article 45 paragraph (2) of PP Number 69 of 1999, Article 48 of PP Number 71 of 2019 and Article 5 PEMKES Number 1787/MENKES/PER/XII/2010. Countermeasures are preventive and repressive. Penalties are subject to Article 378 of the Criminal Code, Article 63 of the UUPK and Article 112 of the Plantation Law.

Keywords: Business Actors, Advertise, Plantation Business Results, Misleading Consumers
\end{abstract}

How to Cite: Winda \& Tedja, K. (2020). Tindak Pidana Mengiklankan Hasil Usaha Perkebunan Yang Menyesatkan Konsumen. Journal of Education, Humaniora and Social Sciences (JEHSS). 3 (1): 17-25.

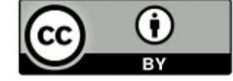




\section{PENDAHULUAN}

Iklan menyesatkan merupakan suatu berita yang mendorong, membujuk khayalak ramai mengenai barang atau jasa yang dijual, dipasang di dalam media massa, namun isi berita yang sajikan belum diketahui kebenarannya yang pasti sehingga dapat merugikan konsumen.

Pada saat ini, banyak bermunculan berbagai produk barang/jasa yang dipasarkan kepada konsumen, baik melalui promosi, iklan maupun penawaran barang secara langsung. Adapun beberapa hal menjadi latar belakang pelaku usaha membuat iklan-iklan menyesatkan, disebabkan ketiadaan sanksi hukum yang tegas terhadap pelaku usaha yang melakukan pelanggaran atas ketentuan iklan serta kurangnya koordinasi antara instansi yang terkait serta tidak berjalannya fungsi pengawasan. Seperti diberitakan oleh Warta ekonomi bahwa "Otoritas Jasa Keuangan (OJK) meminta pelaku industri jasa keuangan untuk tidak menayangkan iklan atau promosi yang tidak jelas dan menyesatkan konsumen.

Menurut Deputi Komisioner Edukasi dan Perlindungan Konsumen 0JK, Sarjito, hal ini melanggar Pasal 10 Undang-undang Nomor 8 Tahun 1999 tentang Perlindungan Konsumen dan Pasal 4 ayat 1 Peraturan OJK Nomor 1 Tahun 2013 tentang Perlindungan Konsumen Sektor Jasa Keuangan. Memuat Pasal 4 ayat 1 POJK Nomor 1/ 2013 Pelaku Usaha Jasa Keuangan wajib menyediakan dan/atau menyampaikan informasi mengenai produk dan/atau layanan yang akurat, jujur, jelas, dan tidak menyesatkan. Untuk itu lanjutnya, pelaku industri jasa keuangan dalam melakukan penawaran dan iklan harus mengikuti Pedoman Iklan yang dianjurkan". Unsurunsur pidana merupakan syarat yang menjadi ciri atau sifat khas dari perbuatan yang dilarang sehingga ancaman pidana kalau dilanggar (Wilbert, dkk., 2020; Sipayung, dkk., 2019; Saragih, dkk., 2019; Azhar dan Elvi Z., 2009).

Adapun unsur-unsur yang terdapat dalam KUHP misalnya Pasal 378 yaitu:

1. Unsur pertama subjektif adalah dengan maksud (met het oogmerk) untuk menguntungkan diri sendiri atau orang lain secara melawan hukum.

2. Unsur kedua objektif terdiri dari :

a. barang siapa

1) menggerakkan orang lain agar orang lain tersebut: a) menyerahkan suatu benda; b) mengadakan suatu perikatan utang; c) meniadakan suatu piutang

2) dengan memakai : a) sebuah nama palsu; b) suatu sifat palsu; c) tipu muslihat; d) rangkaian kata-kata bohong.

Unsur-unsur tersebut sama sekali tidak dimasukkan kegiatan penyampaian informasi menyesatkan melalui iklan sebagai salah satu kegiatan membujuk, sehingga Pasal tersebut ingin dipergunakan untuk menjerat pelaku usaha yang menyampaikan informasi menyesatkan tersebut harus dalam rangka penafsiran Pasal-Pasal KUHP serta ketepatan penggunaan Pasal penipuan ini harus diuji terlebih dahulu melalui putusan pengadilan. Unsur yang masih memerlukan penjelasan berkaitan dengan penerapan Pasal 381 KUHP adalah unsur "menyesatkan". Menyesatkan dalam hal ini berarti melakukan sesuatu perbuatan, sehingga orang yang melihat akan memberikan suatu gambaran yang lain dari keadaan yang sebenarnya.

Berkaitan dengan periklanan, Undang-Undang No. 8 Tahun 1999 Tentang Perlindungan Konsumen memuat pengaturannya bersamaan dengan perbuatan dilarang bagi pelaku usaha khususnya menyesatkan konsumen, yaitu dalam Pasal 10. Pasal 10 menyebutkan bahwa pelaku usaha dalam menawarkan barang dan/atau jasa yang ditujukan untuk diperdagangkan dilarang menawarkan, mempromosikan, mengiklankan atau membuat pernyataan yang tidak benar atau menyesatkan. Larangan ini berlaku bagi para pihak terkait dengan kegiatan periklanan khususnya hasil usaha perkebunan yang menyesatkan.

Terkait mengiklankan hasil usaha perkebunan yang menyesatkan konsumen, maka pengertian perkebunan adalah segala kegiatan pengelolaan sumber daya alam, sumber daya manusia, sarana produksi, alat dan mesin, budi daya, panen, pengolahan, dan pemasaran terkait Tanaman Perkebunan. Hasil Perkebunan adalah semua produk Tanaman Perkebunan dan pengolahannya yang terdiri atas produk utama, produk olahan untuk memperpanjang daya simpan, produk sampingan, dan produk ikutan. 
Tindak pidana perkebunan merupakan perbuatan yang dilarang oleh peraturan yang dikenakan sanksi bagi pelaku yang melanggarnya, guna perlindungan kegiatan dan usaha perekonomian masyarakat di bidang perkebunan. Berdasarkan Pasal 79 Undang-undang No.39 Tahun 2014 Tentang Perkebunan menyatakan bahwa "Setiap Pelaku Usaha perkebunan dilarang mengiklankan hasil Usaha Perkebunan yang menyesatkan konsumen".

Dengan adanya latar belakang seperti yang sudah dipaparkan di atas, maka dengan ini penulis tertarik untuk melakukan penelitian dengan judul "Tindak Pidana Mengiklankan Hasil Usaha Perkebunan Yang Menyesatkan Konsumen". Mengiklankan hasil usaha perkebunan yang menyesatkan konsumen merupakan perbuatan yang tidak memperhatikan nilai dan etika periklanan yang baik, tidak sesuai dengan ketentuan peraturan perundang-undangan yang berlaku.

\section{METODE PENELITIAN}

Jenis penelitian dilakukan dengan hukum normatif merupakan konsep hukum yang tertulis dalam peraturan perundang-undangan atau kaidah/norma manusia. Penelitian ini bersifat deskriptif merupakan gambaran sebuah sifat suatu individu, keadaan, gejala atau kelompok tertentu, atau untuk menentukan ada tidaknya hubungan antara suatu gejala dengan gejala lain dalam masyarakat.

Penelitian hukum normatif menggunakan data: Bahan hukum primer: Perundang-undangan berhubungan dengan permasalahan yang diteliti berupa KUHP, UUPK dan Undang-undang No.39 Tahun 2014 Tentang Perkebunan. Dan Bahan hukum sekunder: Bahan yang memberikan penjelasan mengenai hukum bahan hukum primer berupa buku-buku, makalah, jurnal dan internet. Bahan hukum tersier, yaitu merupakan Kamus Besar Bahasa Indonesia.

Teknik pengumpulan data dengan cara studi kepustakaan. Analisis data yang digunakan berupa analisis kualitatif dilakukan guna mendapatkan data bersifat deskriptif berupa data yang akan diteliti dan dipelajari sesuatu yang utuh.

\section{HASIL DAN PEMBAHASAN}

\section{Tindak Pidana Pelaku Usaha Mengiklankan Hasil Usaha Perkebunan Yang Menyesatkan Konsumen}

Iklan-iklan yang kerap menyesatkan hasil usaha perkebunan, selain pelanggaran dari sisi gambar, gerakan dan bahasa, hal ini juga dikarenakan belum adanya kontrol yang serius terhadap iklan yang menyesatkan. Usaha perkebunan dilakukan baik oleh perorangan maupun badan hukum. Pengaturan tentang perkebunan sebagai bentuk keberpihakan Undang-undang Nomor 39 Tahun 2014 Tentang Perkebunan ini kepada pekebun, termuat dalam beberapa bab terutama pemberdayaan dan pengelolaan hasil usaha perkebunan, pengolahan dan pemasaran hasil Perkebunan.

Usaha Perkebunan adalah usaha yang menghasilkan barang dan/atau jasa Perkebunan. Pelaku Usaha Perkebunan adalah pekebun dan/atau perusahaan Perkebunan yang mengelola Usaha Perkebunan". Hasil Perkebunan merupakan semua produk Tanaman Perkebunan dan pengolahannya yang terdiri atas produk utama, produk olahan untuk memperpanjang daya simpan, produk sampingan, dan produk ikutan. Pelaku tindak pidana sebagaimana dimaksud dalam Undang-undang Nomor 39 Tahun 2014 Tentang Perkebunan adalah setiap orang. Jika pelakunya adalah orang perseorangan, maka tanggung jawab pidananya berada pada orang dimaksud. Akan tetapi, jika pelakunya adalah badan usaha, maka tanggung jawab pidananya berada pada orang yang memberi perintah untuk melakukan tindak pidana. Secara garis besar apabila dilihat dalam Undang-undang Nomor 39 Tahun 2014 Tentang Perkebunan terdapat tindak pidana melakukan perbuatan dilarang khususnya iklan yang menyesatkan. Berikut perbuatan larangan mengiklankan hasil usaha perkebunan yang menyesatkan konsumen dalam Undangundang Nomor 39 Tahun 2014 Tentang Perkebunan yaitu:

a. Setiap Pelaku Usaha Perkebunan dilarang membuka dan/atau mengolah lahan dengan cara membakar. (Pasal 56) 
b. Setiap Pelaku Usaha Perkebunan dilarang mengalihfungsikan Lahan Perkebunan di dalam wilayah geografis yang memproduksi Hasil Perkebunan yang bersifat spesifik. (Pasal 63 ayat (2))

- Setiap Orang dalam melakukan pengolahan, peredaran, dan/atau pemasaran Hasil Perkebunan dilarang: 1) memalsukan mutu dan/atau kemasan Hasil Perkebunan; b) menggunakan bahan penolong dan/atau bahan tambahan untuk pengolahan; dan/atau; c) mencampur Hasil Perkebunan dengan benda atau bahan lain (Pasal 77)

c. Setiap Orang dilarang menadah hasil Usaha Perkebunan yang diperoleh dari penjarahan dan/atau pencurian (Pasal 78)

d. Setiap Pelaku Usaha Perkebunan dilarang mengiklankan hasil Usaha Perkebunan yang menyesatkan konsumen. (Pasal 79)

Di dalam hukum pidana tentang pemberian keterangan yang tidak benar, sebagaimana diatur dalam Pasal 382 bis KUHP, jika dikaitkan dengan dampak dari perbuatan terhadap konsumen, maka perbuatan keterangan yang tidak benar tersebut dapat ditempatkan sebagai penipuan, yang dimuat dalam Pasal 378 KUHP. Penyesatan informasi iklan hasil usaha perkebunan dapat menimbulkan dampak serius kepada konsumen, bukan hanya dari segi jumlah konsumen yang dirugikan tetapi juga dapat berakibat membahayakan bagi konsumen, apabila dilakukan analisis lebih lanjut mengenai penerapan Pasal KUHP dalam rangka pertanggungjawaban pidana para pelaku usaha terkait mengiklankan hasil usaha perkebunan yang menyesatkan konsumen. Menurut KOMINFO sepenuhnya, bahwa seiring makin ketatnya persaingan usaha, maka antar penyelenggara telekomunikasi berusaha meningkatkan kegiatan promosi produk dan layanan telekomunikasi, dimana iklan menjadi salah satu pilihan paling efektif. Namun dengan ketatnya persaingan usaha melalui media iklan saat ini cenderung dapat merugikan masyarakat sebagai calon konsumen karena informasi yang sampai kepada masyarakat selain belum sepenuhnya memenuhi kriteria obyektif, lengkap dan dapat dipertanggung jawabkan, kadang juga mengorbankan kualitas layanannya.

Perbuatan yang dilarang bagi pelaku usaha diatur dalam Bab IV Pasal 8 hingga Pasal 17 UUPK. Unsur-unsur perbuatan yang dilarang dalam periklanan diatur dalam Pasal 17 ayat (1) UUPK yang terdiri dari unsur-unsur sebagai berikut:

a. Mengelabui konsumen mengenai kualitas, kuantitas, bahan, kegunaan, dan harga barang dan/atau tarif jasa serta ketepatan waktu penerimaan barang dan/atau jasa;

b. Mengelabui jaminan/garansi terhadap barang dan/atau jasa;

c. Memuat informasi yang keliru, salah atau tidak tepat mengenai barang dan/atau jasa;

d. Tidak memuat informasi mengenai risiko pemakian barang dan/atau jasa;

e. Mengeksploitasi kejadian dan/atau seseorang tanpa seiizin yang berwenang atau persetujuan yang bersangkutan;

f. Melanggar etika dan/atau ketentuan peraturan perundang-undangan mengenai periklanan. Ketentuan tindak pidana dalam Undang-Undang No. 8 Tahun 1999 Tentang Perlindungan Konsumen termuat dalam Pasal 61 sampai dengan Pasal 63. Sedangkan Peraturan Pemerintah Nomor 69 Tahun 1999 tentang label dan iklan Pangan, mengenai iklan menyesatkan terdapat dalam Pasal 45 yang mengatakan bahwa penerbit, pencetak, pemegang izin siaran radio atau televisi, agen dan atau medium yang dipergunakan untuk menyebarkan iklan, turut bertanggung jawab terhadap isi iklan yang tidak benar (menyesatkan), kecuali yang bersangkutan telah lebih dulu mengambil tindakan yang diperlukan untuk meneliti kembali kebenaran isi iklan yang bersangkutan.Memuat Pasal 48 Peraturan Pemerintah Nomor 71 Tahun 2019 Tentang Penyelenggaraan Sistem Dan Transaksi Elektronik menunjukkan bahwa Pelaku Usaha yang menawarkan produk melalui Sistem Elektronik harus menyediakan informasi yang lengkap dan benar berkaitan dengan syarat kontrak/iklan, produsen, dan produk yang ditawarkan. Pelaku Usaha wajib memberikan kejelasan informasi tentang penawaran iklan.Menurut Peraturan Menteri Kesehatan Nomor 1787/MENKES/ PER/XII/2010 tentang Iklan dan Publikasi Pelayanan Kesehatan menyebutkan bahwa sebuah iklan dan/atau publikasi tidak diperbolehkan apabila bersifat: menyerang dan/atau pamer yang bercita rasa buruk seperti merendahkan kehormatan dan derajat profesi tenaga kesehatan, memberikan informasi atau pernyataan yang tidak benar, wh http://mahesainstitute.web.id/ojs2/index.php/jehss 
palsu, bersifat menipu dan menyesatkan dan memuji diri secara berlebihan, termasuk pernyataan yang bersifat superlatif dan menyiratkan kata "satu-satunya" atau yang bermakna sama mengenai keunggulan, keunikan atau kecanggihan sehingga cenderung bersifat menyesatkan.

\section{Upaya Penanggulangan Tindak Pidana Pelaku Usaha Mengiklankan Hasil Usaha Perkebunan Yang Menyesatkan Konsumen}

Upaya-upaya yang dapat dilakukan untuk menanggulangi tindak pidana pelaku usaha mengiklankan hasil usaha perkebunan yang menyesatkan konsumen yakni upaya preventif dan upaya represif.

1) Upaya preventif yang dilakukan untuk menanggulangi tindak pidana pelaku usaha mengiklankan hasil usaha perkebunan dengan melakukan pembinaan dan pengawasan kepada para pelaku usaha. Pengawasan dilakukan melalui pelaporan dari Pelaku Usaha Perkebunan dan pemantauan serta evaluasi terhadap pelaksanaan dan hasil Usaha Perkebunan. Dalam hal tertentu pengawasan dapat dilakukan melalui pemeriksaan terhadap proses dan hasil perkebunan.

2) Upaya represif ini dipergunakan jika terjadi kerugian konsumen terhadap iklan hasil usaha perkebunan yang menyesatkan konsumen karena hak konsumen akan informasi yang tidak dipenuhi. Upaya penanggulangan dengan represif ini berupa sarana penjatuhan sanksi atau hukuman terhadap pelaku usaha mengiklankan hasil usaha perkebunan yang menyesatkan konsumen untuk memberikan efek jera. Demikian upaya-upaya yang dapat dilakukan oleh aparat kepolisian dan pengawasan oleh pemerintah pusat dan daerah dilaksanakan oleh Menteri dan/atau Menteri teknis terkait dan masyarakat serta lembaga perlindungan konsumen swadaya masyarakat agar tidak terjadi Tindak Pidana mengiklankan hasil usaha perkebunan yang menyesatkan konsumen.

3. Hukuman Bagi Pelaku Mengiklankan Hasil Usaha Perkebunan yang Menyesatkan Konsumen Pelanggaran kegiatan iklan yang dapat dipidana berdasarkan ketentuan Pasal 62 UndangUndang No. 8 Tahun 1999 Tentang Perlindungan Konsumen tersebut meliputi pelanggaran kegiatan periklanan hasil usaha perkebunan yang menyesatkan konsumen yang dapat diancam pidana adalah sebagaimana diatur dalam Pasal 8, Pasal 9, Pasal 10, Pasal 13 ayat (2), Pasal 17 ayat (1) huruf a, b, c, e, Pasal 17 ayat (2). Ketentuan Pasal 62 Undang-Undang No. 8 Tahun 1999 Tentang Perlindungan Konsumen tersebut didasarkan jenis sanksi pidana yang dapat dijatuhkan kepada pelaku tindak pidana, terbagi atas dua tingkatan yaitu sanksi pidana penjara paling lama 5 (lima) tahun atau pidana denda dan sanksi pidana penjara paling lama 2 (dua) tahun atau pidana denda. Kemudian, sanksi pidana berupa denda yang diancamkan Pasal 62 termasuk dalam jenis hukuman pidana pokok dalam KUHP sebagaimana ditentukan dalam Pasal 10 KUHP, yaitu: a) Hukuman mati; b) Hukuman penjara; c) Hukuman kurungan; d) Hukuman denda

Dalam Pasal 62 Undang-Undang No. 8 Tahun 1999 Tentang Perlindungan Konsumen ini juga dapat didasarkan kepada tingkat pelanggaran yang dilakukan oleh pelaku usaha. Selain dapat dikenakan sanksi pidana pokok sebagaimana diatur dalam Pasal 62 Undang-Undang No. 8 Tahun 1999 Tentang Perlindungan Konsumen, pelaku usaha sesuai ketentuan Pasal 63 Undang-Undang No. 8 Tahun 1999 Tentang Perlindungan Konsumen dapat pula diancam dengan hukuman tambahan, berupa: a) Perampasan barang tertentu; b) Pengumuman keputusan hakim; c) Pembayaran ganti rugi; e) Perintah penghentian kegiatan tertentu yang menyebabkan timbulnya kerugian konsumen; f) Kewajiban penarikan barang dari peredaran; g) Pencabutan izin usaha

Hukuman pidana tambahan sebagai pendamping hukuman pidana pokok diaplikasikan bersamaan dengan hukuman pidana tambahan dalam KUHP yaitu: a) Pencabutan beberapa hak yang tertentu; b) Perampasan barang tertentu; c) Pengumuman keputusan hakim

Mempertimbangkan potensi bahaya yang dapat timbul dari pemberian informasi iklan yang menyesatkan terhadap konsumen, maka pengenaan Pasal-Pasal KUHP tidak hanya mengenai Pasal-Pasal penipuan dengan ancaman pidana penjara maksimal 4 (empat) tahun penjara, seperti Pasal 378, 382 bis, 383 dan 386 ayat (1) KUHP, tetapi dapat pula dikenakan Pasal-Pasal pidana dengan ancaman pidana yang lebih berat. Pelaku usaha mengiklankan hasil usaha perkebunan 
yang menyesatkan konsumen sesuai dengan ketentuan Pasal 63 Undang-Undang No. 8 Tahun 1999 Tentang Perlindungan Konsumen dapat pula diancam dengan hukuman tambahan bagi pelaku usaha berupa perampasan barang tertentu, pengumuman keputusan hakim, pembayaran ganti rugi, perintah penghentian kegiatan tertentu yang menyebabkan timbulnya kerugian konsumen, kewajiban penarikan barang dari peredaran dan pencabutan izin usaha. Kenyataan izin perkebunan yang tumpang tindih antara izin dan kewenangannya, diatur kembali dan mengamanatkan pembangunan sistem data dan informasi perkebunan yang lebih modern dan menjadi dasar hukum baru untuk pemberian sanksi bagi pejabat dan pengusaha yang melanggar Undang-undang Perkebunan. Pasal 72 ayat (1) dan (2) Undang-undang Nomor 39 Tahun 2014 Tentang Perkebunan menegaskan bahwa Usaha Pengolahan Hasil Perkebunan dilakukan untuk memperoleh nilai tambah.

Pasal 110 Undang-undang Nomor 39 Tahun 2014 Tentang Perkebunan bahwa: "Setiap Orang yang dalam pengolahan, peredaran, dan/atau pemasaran Hasil Perkebunan yang melakukan pemalsuan mutu dan/atau kemasan Hasil Perkebunan, penggunaan bahan penolong dan/atau bahan tambahan untuk pengolahan; dan/ atau pencampuran Hasil Perkebunan dengan benda atau bahan lain yang dapat membahayakan kesehatan dan keselamatan manusia, merusak fungsi lingkungan hidup, dan/atau menimbulkan persaingan usaha tidak sehat dipidana dengan pidana penjara paling lama 5 (lima) tahun dan denda paling banyak Rp5.000.000.000,00 (lima miliar rupiah). Perlindungan terhadap konsumen telah melahirkan Undang-Undang No. 8 Tahun 1999 Tentang Perlindungan Konsumen, yang berfungsi sebagai payung hukum bagi pengaturan perlindungan konsumen yang telah ada sebelumnya. Melalui ketentuan tersebut dapat dipahami secara implisit, bahwa Undang-Undang No. 8 Tahun 1999 Tentang Perlindungan Konsumen merupakan ketentuan khusus (lex specialis). Namun ketentuan di luar Undang-Undang No. 8 Tahun 1999 Tentang Perlindungan Konsumen tetap berlaku sepanjang tidak diatur secara khusus atau tidak bertentangan dengan Undang-Undang No. 8 Tahun 1999 Tentang Perlindungan Konsumen sesuai dengan Pasal 64 Bab XIV. Sedangkan ketentuan peraturan perundang-undangan yang sudah ada sebelum Undang-undang No. 8 Tahun 1999 Tentang Perlindungan Konsumen disebut lex generalis. Lex generalis mengesampingkan aturan yang bersifat umum dan tidak lagi sebagai hukum ketika telah ada aturan yang bersifat khusus. Ketentuan-ketentuan lex specialis harus berada dalam lingkungan hukum (rezim) yang sama dengan lex generalis. Oleh karena adanya Undang-undang Nomor 39 Tahun 2014 Tentang Perkebunan, maka Undang-undang No. 8 Tahun 1999 menjadi khusus (lex specialis) atas tindak pidana pelaku usaha mengiklankan yang menyesatkan bagi konsumen yang terjadi hasil usaha perkebunan. Konsekuensi yuridis dari penggunaan Pasal 28 ayat (1) Undang-undang No.11 Tahun 2008 Tentang Informasi dan Transaksi Elektronik terhadap Pasal 378 KUHP pada tindak pidana pelaku usaha menyesatkan konsumen pada media sosial adalah kedua Pasal dalam dua undang-undang tersebut saling mengesampingkan dan mengecualikan. Iklan yang menyesatkan konsumen diatur dalam Pasal 28 ayat 1 Undang-undang No.11 Tahun 2008 Tentang Informasi dan Transaksi Elektronik dalam Bab VII Perbuatan Terlarang berbunyi "Setiap orang dengan sengaja, dan tanpa hak menyebarkan berita bohong dan menyesatkan yang mengakibatkan kerugian konsumen dalam Transaksi Elektronik." Ketentuan pidana terkait pelanggaran itu ada dalam Pasal 45 ayat 2 Undang-undang No.11 Tahun 2008 Tentang Informasi dan Transaksi Elektronik. Bagi pihak yang melanggar bisa dipidana dengan ancaman kurungan penjara paling lama enam tahun dan atau denda paling banyak Rp1.000.000.000,00 (satu miliar rupiah).

Mengenai sanksi yang diberikan apabila melanggar apa yang sudah di tentukan dalam peraturan Peraturan Pemerintah Nomor 69 Tahun 1999 tentang Label dan iklan Pangan, tertuang dalam Pasal 61 yang menetapkan bahwa sanksi yang diberikan adalah sanksi administratif. Untuk jenis sanksinya di atur dalam Pasal 61 ayat (2) Peraturan Pemerintah tersebut, yaitu: a) peringatan secara tertulis; b) larangan mengedarkan untuk sementara waktu dan/atau perintah untuk menarik produk pangan dari peredaran; c) pemusnahan pangan jika terbukti membahayakan kesehatan dan jiwa manusia; d) penghentian produksi untuk sementara waktu; e) pengenaan denda paling tinggi Rp. 50.000.000,00 (lima puluh juta rupiah), dan atau; f) pencabutan izin produksi atau izin usaha. 
Tabel 1 Perbuatan Pidana dan Ancaman Hukum Kepada Pelaku Tindak Pidana Mengiklankan Hasil Usaha Perkebunan yang Menyesatkan Konsumen

\begin{tabular}{|c|c|c|c|c|}
\hline No & KUHP & $\begin{array}{l}\text { UU No.8 Tahun } 1999 \\
\text { Tentang Konsumen }\end{array}$ & $\begin{array}{l}\text { UU Nomor } 39 \text { Tahun } 2014 \\
\text { Tentang Perkebunan }\end{array}$ & $\begin{array}{l}\text { UU No.11 Tahun } 2008 \\
\text { Tentang ITE }\end{array}$ \\
\hline 1 & $\begin{array}{l}\text { Perbuatan } \\
\text { dilarang: } \\
\text { Pasal } 382 \\
\text { Pasal } 386\end{array}$ & $\begin{array}{l}\text { Perbuatan dilarang: } \\
\text { Pasal } 9 \\
\text { Pasal } 10 \\
\text { Pasal } 17\end{array}$ & $\begin{array}{l}\text { Perbuatan dilarang: } \\
\text { Pasal } 77 \\
\text { Pasal } 79\end{array}$ & $\begin{array}{l}\text { Perbuatan dilarang: } \\
\text { Pasal } 28 \\
\text { Pasal } 36\end{array}$ \\
\hline 2 & $\begin{array}{l}\text { Ancaman } \\
\text { Hukuman } \\
\text { Pidana Pokok } \\
\text { Pasal } 378 \\
\end{array}$ & $\begin{array}{l}\text { Ancaman Hukuman } \\
\text { Pidana Pokok } \\
\text { Pasal } 62\end{array}$ & $\begin{array}{l}\text { Ancaman Hukuman Pidana } \\
\text { Pokok } \\
\text { Pasal } 112\end{array}$ & $\begin{array}{l}\text { Ancaman Hukuman } \\
\text { Pidana Pokok } \\
\text { Pasal } 45\end{array}$ \\
\hline 3 & $\begin{array}{l}\text { Ancaman } \\
\text { Hukuman } \\
\text { Pidana } \\
\text { Tambahan } \\
\text { Pasal } 383\end{array}$ & $\begin{array}{l}\text { Ancaman Hukuman } \\
\text { Pidana Tambahan } \\
\text { Pasal } 63\end{array}$ & $\begin{array}{l}\text { Ancaman Hukuman Pidana } \\
\text { Tambahan } \\
\text { Pasal } 113\end{array}$ & $\begin{array}{l}\text { Ancaman Hukuman } \\
\text { Pidana Tambahan } \\
\text { Pasal } 52\end{array}$ \\
\hline
\end{tabular}

Menurut Pasal 100 ayat (2), (3), (4) dan (5) Peraturan Pemerintah Nomor 71 Tahun 2019 Tentang Penyelenggaraan Sistem dan Transaksi Elektronik ditegaskan bahwa sanksi administratif dapat berupa: teguran tertulis, denda administratif, penghentian sementara, pemutusan Akses dan/atau dikeluarkan dari daftar.

Pasal 35 ayat (1), (2) dan (3) Peraturan Pemerintah Nomor 71 Tahun 2019 Tentang Penyelenggaraan Sistem dan Transaksi Elektronik bahwa Menteri berwenang melakukan pengawasan terhadap penyelenggaraan Sistem Elektronik. Pengawasan mencakup pemantauan, pengendalian, pemeriksaan, penelusuran, dan pengamanan. Ketentuan mengenai pengawasan atas Sistem Elektronik dalam sektor tertentu wajib dibuat oleh Kementerian atau Lembaga terkait setelah berkoordinasi dengan Menteri. Berdasarkan Peraturan Menteri Kesehatan Nomor 1787/MENKES/PER/ XII/2010 mengenai fasilitas pelayanan kesehatan dan/atau tenaga kesehatan tidak mengubah, menarik, menghilangkan, dan/atau menghentikan iklan dan/atau publikasi, Menteri Kesehatan dan/atau kepala dinas yang menyelenggarakan urusan pemerintahan daerah dapat mengambil tindakan administratif berupa pencabutan izin operasional. Tindakan administratif harus dilaksanakan dalam jangka waktu paling lama 30 hari kerja. Dalam pengawasan iklan dilakukan tim penilaian dan pengawasan iklan dan publikasi pelayanan kesehatan di lingkungan kementerian kesehatan.

\section{SIMPULAN}

Iklan yang menyesatkan hasil usaha perkebunan secara umum diatur dalam KUHP termasuk dalam tindak pidana penipuan Pasal 378 KUHP, secara khusus dalam Pasal 10 Undang-undang No. 8 Tahun 1999 tentang Perlindungan Konsumen, Pasal 79 Undang-undang No.39 Tahun 2014 Tentang Perkebunan, Pasal 45 ayat (2) Peraturan Pemerintah Nomor 69 Tahun 1999 tentang Label dan iklan Pangan, Pasal 48 Peraturan Pemerintah Nomor 71 Tahun 2019 Tentang Penyelenggaraan Sistem Dan Transaksi Elektronik dan Pasal 5 Peraturan Menteri Kesehatan Nomor 1787/MENKES/ PER/XII/2010 tentang Iklan dan Publikasi Pelayanan Kesehatan. Upaya penanggulangan tindak pidana pelaku usaha mengiklankan hasil usaha perkebunan yang menyesatkan konsumen dilakukan dengan dua cara yaitu preventif dan represif. Hukuman bagi pelaku mengiklankan hasil usaha perkebunan yang menyesatkan konsumen adalah Pasal 378 KUHP merupakan Pasal mengenai penipuan, sedangkan Pasal 63 UUPK merupakan ancaman hukuman pidana tambahan dan Pasal 112 Undang-undang Nomor 39 Tahun 2014 Tentang Perkebunan merupakan ancaman hukuman pidana pokok. 


\section{DAFTAR PUSTAKA}

Ali, Z. (2014). Metode Penelitian Hukum. Jakarta : Sinar Grafika.

Amiruddin dan H. Zainal. (2013). Pengantar Metode Penelitian Hukum. Jakarta : Rajawali Pers.

Atsar, A. \& Apriani, R. (2019). Buku Ajar Hukum Perlindungan Konsumen. Yogyakarta: Deepublish.

Azhar dan Elvi Z., (2009), Penegakan Hukum dalam Tindak Pidana Merek Terkenal, Mercatoria, 2 (2): 13 127

Chazawi, A. (2003). Kejahatan Terhadap Harta Benda. Malang : Bayumedia.

Ediwarman. (2015). Metodologi Penelitian Hukum. Medan : PT Sofmedia.

Gunanegara. (2019). Hukum Perkebunan: Sejarah \& Latar Belakangnya. Jakarta : PT. Adhi Sarana Nusantara.

Harianto, D. (2010). Perlindungan Hukum Bagi Konsumen Terhadap Iklan Yang Menyesatkan. Ghalia Indonesia.

Iskandar Muda Sipayung, Tan Kamello, Marlina \& Arie Kartika. (2019). Perjanjian Jaminan Fidusia Kaitan dengan Penyidikan Tindak Pidana Perlindungan Konsumen. ARBITER: Jurnal Ilmiah Magister Hukum. 1(2): 157-166.

Julimaster Saragih, Marlina \& Muaz zul. (2019). Penyidikan Terhadap Tindak Pidana Penyalahgunaan Izin Lokasi. ARBITER: Jurnal Ilmiah Magister Hukum, 1(1) 2019: 11-18.

Khoiruman, M. (2015). Model Perlindungan Hukum Konsumen Terhadap Periklanan Surat Kabar (Studi Kasus Surat Kabar Lokal Di Surakarta). Jurnal Jurisprudence. 5 (2): 111

Lamintang, P.A.F. \& Lamintang, T. (2009). Kejahatan Terhadap Harta Kekayaan. Jakarta : Sinar Grafika.

Miru, A. \& Yodo, S.. (2011). Hukum Perlindungan Konsumen. Jakarta : Rajawali Pers.

Miru, A. (2013). Prinsip-Prinsip Perlindungan Hukum Bagi Konsumen di Indonesia. Jakarta : Rajawali Pers.

Muthiah, A. (2018). Hukum Perlindungan Konsumen : Dimensi Hukum Positif dan Ekonomi Syariah. Yogyakarta : Pustaka Baru Press.

Puspitasari, I. (2018). Pertanggungjawaban Pidana Pelaku Tindak Pidana Penipuan Online Dalam Hukum Positif di Indonesia. Jurnal HUMANI (Hukum dan Masyarakat Madani). 8 (1): 12

Rosmawati, (2018). Pokok-pokok Hukum Perlindungan Konsumen. Depok : Prenadamedia Group.

Rukmini, A. (2006). Aspek Hukum Pidana dan Kriminologi (sebuah Bunga Rampai). Bandung : PT. Alumni.

Rusdiana. E. (2010). Aspek Pidana Iklan yang Menyesatkan Pada Undang-Undang No. 8 Tahun 1999 tentang Perlindungan Konsumen. Jurnal Pamator. 3 (1): 7

Sara, I.M., Saputra, K.A.K. \& Jayautama, I.W.K. (2018). Aspek Hukum Dalam Bisnis. Sidoarjo : Indomedia Pustaka.

Sari, E.K. \& Simangunsong, A. (2005). Hukum Dalam Ekonomi. Jakarta : PT. Gramedia Widiasarana Indonesia. Shidarta, Rasyid, A. \& Sofian, A. (2019). Aspek Hukum Ekonomi dan Bisnis. Jakarta : Prenadamedia Group.

Sidabalok, J. (2010). Hukum Perlindungan Konsumen di Indonesia. Bandung : PT. Citra Aditya Bakti.

Sidauruk, H.P. (2014). Penegakan Hukum Dalam Tindak Pidana Lingkunga Hidup Menurut UU No. 18 Tahun 2004 Tentang Perkebunan. Jurnal Nestor Magister Hukum. 2 (4): 13

Tongat \& Sunaryo, S. (2014). Rekonstruksi Konsep Penanggulangan Tindak Pidana Dengan Hukum Pidana Berbasis Nilai Tradisional. Jurnal MMH. 43 (2): 242

Tongat. (2003). Hukum Pidana Materiil. Malang : UMM Press.

Wibowo, M. (2018). Iklan Televisi dan Perlindungan Hukum Bagi Konsumen. Bandung : CV. Mandar Maju.

Wilbert, W., Wau, K., \& Chelsia, V. (2020). Tinjauan Yuridis Terhadap Tindak Pidana Perdagangan Mie Kuning Basah dengan Menggunakan Bahan Formalin (Putusan Nomor 2796/Pid.Sus/2018/PN Mdn). JURNAL MERCATORIA, 13(1), 62-74. doi:https://doi.org/10.31289/mercatoria.v13i1.3645

Kitab Undang-undang Hukum Pidana (KUHP)

Undang-Undang Nomor 8 Tahun 1999 Tentang Perlindungan Konsumen (Lembaran Negara Republik Indonesia Tahun 1999 Nomor 42, Tambahan Lembaran Negara Republik Indonesia Nomor 3821).

Undang-Undang Nomor 39 Tahun 2014 Tentang Perkebunan (Lembaran Negara Republik Indonesia Tahun 2014 Nomor 308, Tambahan Lembaran Negara Republik Indonesia Nomor 5613).

Undang-Undang Nomor 19 Tahun 2016 Tentang Perubahan atas Undang-Undang Nomor 11 Tahun 2008 Tentang Informasi dan Transaksi Elektronik (Lembaran Negara Republik Indonesia Tahun 2016 Nomor 251, Tambahan Lembaran Negara Republik Indonesia Nomor 5952).

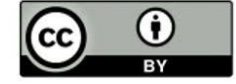

